\title{
'The new but lonely voice against the authoritarianism': humor and irony in Turkish political discourse after the Taksim Gezi Park Protests
}

\author{
Gunes Aksan \\ Istanbul Bilgi University \\ geaksan@gmail.com
}

\begin{abstract}
This study investigates the diffusion of a new political language based on humour and irony into Turkish politics. The Taksim Gezi Park Protests, in addition to introducing a new subject to Turkish politics, led to a new language that places humour at the centre. The Government's neoliberal and authoritarian policies and tight control over traditional media shaped the resistance to be humoristic and indirect. People used alternative media to voice their dissent, mainly in the form of social media messages in addition to street performances, graffiti, videos and murals. This new wave of humour, which I prefer to call the "public square humour" emphasised creativity, improvisation and pluralism via the usage of traditional conversational humour mechanisms of the Turkish folk narratives. I investigate the effect of this new wave of humour on the professional politicians over the course of following years after the protests in an increasingly authoritarian political climate. I analyse the Twitter messages of four major party leaders and politicians who are active in Twitter, both qualitatively and quantitatively. With the methods of the discourse analysis I identify the political parties that embrace the new language of the political opposition. Finally, I conclude that Demirtas embraces the public square humour better and makes use of it to underline the transformation of HDP (People's Democratic Party) from a defendant of ethnic politics to the representative of the new voice of Turkish political opposition.
\end{abstract}

Keywords: humour, irony, Twitter, politicians, Taksim Gezi Park protests.

\section{Introduction}

In the recent years, a number of newspaper articles and interviews have covered the growing appetite for the use of humour in Turkish politics (Koc 2014; Altan 2014; Tastekin 2014; Civaoglu 2015; Aral 2015). These articles criticise not only today's political leaders for their lack of ability to make use of humour, but also growing humourless climate in the political 
sphere. In contrast to the formal political scene, beginning from 1990s, humour has secured its position as a cultural practice. Aside from twenty weekly humour magazines, numerous leisure magazines as well as comedy specific cultural centres and café-bars, YouTube channels, web dictionaries, books and blogs sprung up with titles that advertised their humorous content. While these different humorous products detailed the cultural aspects of everyday life of urbanites, they are simultaneously less involved with formal politics and professional politicians. In fact, the silence on the part of the political humour and satire accompanied the relative silence of the political opposition against the hegemony of the ruling party. One of the reasons of the feeble voice of the opposition can be found in the depoliticization process of the political life started by the 1980-83 military regime by arresting, trying and incarcerating thousands of people. The influence of this military regime remained even after the 1983 transition to democracy and implementation of neoliberal policies by the ruling Motherland Party (Anavatan Partisi, ANAP). As a result, youth who came of age in the post-1980 period are seen as the generation of the military coup, neoliberalism and the consumer society (Lukuslu 2014: 78). With the Justice and Development Party (Adalet ve Kalkinma Partisi, AKP), the process of commodification under the neoliberal capitalism went hand in hand with the development of new police state techniques (Tugal 2013: 148). In 2016, under the rigid rule of AKP two thousand lawsuits have been filed for insulting the president Recep Tayyip Erdogan. As a result, Turkey fell down to 151st place in the 2016 World Press Freedom Index (BBC 2016; Reporters 2016). Between the years 2004-2015, the five lawsuits opened against the cartoonists or their publishers represent the anti-humour attitudes coming from the ruling party, the AKP and in particular its de facto leader Recep Tayyip Erdogan. In this era, while humour as a cultural practice has been diffusing deeply in the informal routes of daily life, it has been simultaneously evicted from the formal politics. This is one of the reasons why the Taksim Gezi Park protests took place; they were immediately labelled as a movement of an apolitical generation who grew up with humour (Ayata 2014) (Kongar \& Kucukkaya 2013). During the Taksim Gezi Park protests, we witnessed an extraordinary resurgence of interest in humour as well as its use as a political tool for the creation of the democratic atmosphere in which different visions can coexist. In this sense, this paper argues that the Taksim Gezi Park protests created a critical moment by putting the humour back in politics.

In addition to this periodical dimension, humour of the Taksim Gezi Park protests has a social class dimension as well. According to Kuipers, humour is a very potent way of drawing symbolic boundaries. The use and appreciation of humour is related to social background (Kuipers 2009: 219). In the Taksim Gezi Park context we've seen a particular utilisation of humour for the benefit of groups who became economically, culturally or politically disadvantaged under the politics of AKP. The Taksim Gezi Park protests is a middle class reaction to the government's privatisation policy of public places and increasingly authoritarian policies, and it allowed them to show their vision of the urban living (Keyder 2014; Gole 2013; Tugal 2013; Wacquant 2014; Ayata 2014; Kongar \& Kucukkaya 2013). Even though having good sense of humour is a social marker, and consumption of it is also based on socioeconomic conditions, humorous repertoires are massively shared for the most of the society (Firedman 2011). And in the hands of the Taksim Gezi Park protesters the repertoire of popular humour became a useful political tool to share the cause of the movement and reach diverse social actors. During the protests, the protesters defined their extensive usage of humour with the expression of the "disproportionate use of intelligence" emphasising their ability to make humour against the bigotry of the government and its disproportionate police brutality without hesitation. Even though the movement rose in middle class, their call for engagement was also an appeal for solidarity that was established by means of shared aspects of personal identity: being intelligent enough to make humour. This point of view considers humour as well as intelligence one of the tools for opposing the authority (Emre et al. 2014: 430). This feature of 
the Taksim Gezi Park movement indeed seems to be in line with the contemporary worldwide trend of mass revolts against repressive regimes as exemplified by the Arab Spring uprisings, the March of Millions protests in Russia and mass protests in Brazil. Another stylistic commonality of these movements is sit-ins at the public squares. Tugal points out that, during the occupation of the town squares, protesters experience a non-commodified space where they momentarily tasted the fruit of a solidaristic life (2013: 157). On the other hand, Ors noted that the occupation of public squares is intimately linked with the crises of democracy (2014: 490). The humorous language born from these moments of freedom and solidarity, which I prefer to call the "public square humour", provides the common ground that facilitates the communication as well as the confrontation of different political visions between protesters. In the light of recent studies and commentaries on the Taksim Gezi Park movement, the present research investigates whether the humorous language born at the public squares of Istanbul and many other cities of Turkey has an effect on formal politics in the context of electoral competition. My point of departure is that during the protests; pluralism, improvisation and creativity reappeared in the terrain of humour to shift balances of power. In this way, the protesters turned a public square into a commune by creating a festive atmosphere in which language of humour enhanced communication with diverse people or groups, who have been barred from the formal politics for years, such as LGBT, Anti-capitalist Muslims, feminist and green movements and middle class youth who has never been a part of the leftist politics. In my analysis I will argue that the role of the new language of humour in resolving the on-going tension between the rejection of the formal politics by certain section of the society and their demand to participate in actual politics, which affects their life deeply.

\section{Review of the literature}

Politics and humour share the same paradoxical nature; they are both universal and particular. Their nature is starting from the need of human beings to become socialised then establish a pacte sociale for living together. The pacte either provides the protective umbrella of the social order and sets restrictions on our liberty. The tension between adaptation to imposed rules of the social order and pursuit of liberty constitutes universal aspect of any society. The problematic remains at the centre of today's political philosophy "the question of creating the setting for a shared life free of domination" (Axtmann 2013: 128). A version of the same problem is present in Bakhtinian theories of humour as well: how necessary is the courage of laugh to the pursuit of liberty? (Holquist 1984). One branch of theories of humour also discusses the role of humour for the creation of particular moments of liberty from the pressures of the social order (Bergson 1914; Bakhtin 1984; Douglas 2002). In Rabelais and his world, Bakhtin exposed in detail the indispensable role of the folk humour and carnival experience for the consolidation of political power in the feudal societies of the Middle Ages. He sees the carnival experience of the people as a process in which "people in the town square realise that established truth and authority are relative" (Bakhtin 1984: 255).

According to him, "the carnivalesque crowd in the streets is outside of and contrary to all existing forms of the coercive socioeconomic and political organisation, which is suspended for the time of the festivity" (1984: 255). In this sense, the carnival laughter creates counterhegemonic moments, which change the position of the laughter in favour of the subversive. Although these carnivalesque moments are temporary, they do break the hegemony for a shortlived pause and leave marks in both social consciousness and social unconsciousness (Sorensen 2014; Emre et al. 2014). In the perspective of critical political theory, Bruner also argues that while these carnivalesque moments can serve to reinforce political order, they are also ultimately capable of serving a much greater purpose; "allowing subjects to enter a liminal 
realm of freedom and in so doing create a space for critique that would otherwise not be possible in "normal" society" (2005: 140). In the context of the Taksim Gezi Park, Ors elaborates the commune experience of protesters as a creative display of democratic vision beyond its limited definition as the rule of elected people. For her, this experience could no longer be taken from the people. It was to be an inclusionary democracy where people became active residents of their city and engaged in how they were to be ruled (Ors, 2014:495-6). One of the slogans of the protesters reflects their critic on the authoritarian decisions of the government as well as the operation of democracy in Turkey: "Gas, Gas, Gas, it is the only way they deal with problems".

Even though the contemporary studies of humour as a corrective control (Paton et al. 1988; Billig 2005) indicates the importance of the humour for the reproduction of social order, an increasing number of studies discuss the subject for the creation of a new culture of resistance in the context of current wave of protests in diverse places like Egypt, Brazil, Russia and Turkey (Makarychev 2013; Anagondhalli and Khamis 2014; Emre et. al. 2014; Morva 2016; Kaptan 2016). The rising number of authoritarian leaders in diverse geographies puts the subversive humour in the agenda of humour studies again. Sorensen, for instance, in her study of the humorous strategies of the Serbian group Otpor to resist the dictatorship during the rule of Slobodan Milosevic, suggests that humour has a number of functions for such non-violent resistance movements: it facilitates mobilisation and a culture of resistance and affects the relationship between the movement and oppressor (2014:83-84). Makarychev's study on antiPutin humour narratives during the March of Millions protests points out two major functions of humour: deconstruction of hierarchies of power and expansion of the circle of protesters (2013). The study of the Taksim Gezi Park protests evaluated from the same perspective focuses on the language of humour as the weapon of the weak under the repressive regime. The humorous repertoire of the movement composed of slogans, graffiti, murals and street performances is analysed in the perspective of Bakhtinian carnival (Sener 2013; Emre et al. 2014; Gorkem 2015; Morva 2016). Each of these studies demonstrates in different way how humour became a language of the dissent as well as a political act.

Considering the present study as an attempt to investigate the possible effect of the humorous critic of the on-going political discourse, the study of the politicians' use of humour constitutes the major subject of interest. The area of parliamentary discourse of political humour was rarely analysed in Turkish studies before the Taksim Gezi Park protests. Passerat's study of the political party leaders' parliamentary speeches during the Taksim Gezi Park protests shows that irony is an effective narrative tool for the Turkish politicians (2014). For her, the extensive usage of irony in such a tense atmosphere by the Prime Minister Recep Tayyip Erdogan and the leader of the main opposition party, the Republican People's Party, Kemal Kilicdaroglu in the Turkish parliament, reflects a highly polarised political discourse in which the debate on how the message is put into shape becomes more important than what is said (Passerat 2014: 222).

After the Taksim Gezi Park protests the usage of social media tools by politicians has become a popular subject as well. These studies show that there is a growing interest of Turkish politicians to the social media for reaching their audiences in the post-Gezi park period, but they also indicate that the interest is limited since the politicians still use the online social networks as a traditional one-way communication channel without recognising their interactive and participatory nature (Dogu et al. 2014).

In the context of politicians' use of humour, Tsakona examined the Greek parliamentary speeches on the usage of irony and punning. Her findings illustrate that humorous narratives fulfil three functions for politicians. They help to construct political identities, attack the views of their adversaries and attract the media attention (Tsakona 2011, 2013). Mueller examined 
the humorous narrative in the German Parliament as well. His analysis shows that laughter and amusement serve as a marker of aggressiveness and conciliation to different degrees (2011).

In sum, studies in political humour usually describe humour either as a form of expressing criticism and aggression in a mitigated and socially acceptable manner and effective way for acquiring political knowledge (Tsakona 2013; Corner 2012), or as a form of rebellion against the official picture of events or culture of formal democracy (Scott 1990; Goldstein 2003; Sorensen 2014). My analysis posits itself in between; while defining humour as the language of the Taksim Gezi Park movement by underlining its subversive potential, it focuses on its possible expansion to the formal politics in the hands of professional politicians for expressing their ideas or critics. Before analysing humour of the politicians, we need to identify the humour of the Taksim Gezi Park resistance, which I will define as the public square humour.

\subsection{The public square humour}

The Taksim Gezi Park movement brings to mind another affiliation between humour and politics in the historical context. They both have a specific spatial dimension. Demos [people, public] need agora for debating how to rule the kratos [power, rule], humour needs agora as a "carnival square" for making room for a multiplicity of voices and meanings reversing the serious world of the kratos. The public square where the agora locates or carnival takes place, therefore, symbolically represents a crucial aspect of the formal political practice as well as the rejection of it with the carnivalesque humour. The Gezi resistance allows us to evaluate the importance of physical space for elaborating power relations between ordinary citizens and political and economic authorities (Gole 2013; Ors 2014). Due to the Taksim Gezi Park movement's insistence to enter the square during the first two days of protests, people symbolically gained their right to gather at this historically important square as well as to use their freedom of speech. As a result, humour entered the public square with its festive spirit. As the cartoonist Bahadir Baruter puts it: "the humour returned to the streets" (Baruter 2013). From the interviews with protesters at the Taksim Gezi Park, Collin (2015) quotes a parallel perspective from the eyes of a protester: "Laughter played a crucial role, in those days in Taksim square, laughing at the politicians seemed somehow to drain their power, puncturing their certainties and making them shrivel like pricked balloons, their speeches reduced to comical glossolalia".

During the occupation of the Park, the anonymity and cooperation in the communal life of protesters created a specific kind of communication. As Bakhtin describes, "a special kind of communication occurs in the spirit of carnival, frank and free, and free from norms of etiquettes" (1984: 135). In this pluralistic and creative communication setting at the Taksim Square the urban middle classes reinvented the folk culture of humour as a reflex of the resistance (Ozgen 2013: 7). According to Ozgen, during the protests, Nasreddin Hodja humour returned to his village (2013: 7). Departing from the Bakhtin's carnival, Ozgen makes an association between the ancient Anatolian folk humour tradition and the Taksim Gezi Park's humorous murals. For her, the search for freedom is the common motif for both Nasreddin Hodja humour of Anatolia and the Taksim Gezi Park's humorous language.

The long oral tradition of the folk humour is shaped by its condition of production, namely, the lack of freedom of speech (Nesin 2011: 286-92). Nesin, one of the most prominent Turkish humourists, defines folk humour as "a tool to find a solution to people's problems by making them laugh" (2011: 339). He emphasises its universally subversive nature. He notes that "all kind of folk humour should be useful for the people who suffer from the unfairness of the social structure and the oppressive politics" (Nesin 2011: 338). The Nasreddin Hodja character, for example, was a humorous figure who challenged the official culture and transcended every boundary imposed by society through an instrumental foolishness and spontaneous cleverness 
(Gurkas 2008:120). His stories are noteworthy with their erotic, satirical and grotesque character in which we can find the particularities of the subversive humour (Boratav 1988). Therefore, they are analysed with the Bakhtinian conceptualisation of folk humour (Scott 1990; Gurkas 2008; Ozgen 2013). While Gurkas (2008) sorts out the characteristic of the short oral stories of Nasreddin Hodja, he also defines the qualifications of oral folk humour: "short, formulaic and sometimes startling, easy to remember, convenient for transfiguring proverbial sayings and circulating among people". He also mentions Scott's notice: "the control of oral culture is almost impossible since it's secluded, anonymous and decentralized" (Scott 1990: 4).

The physical proximity in the carnivalesque atmosphere of the public square provokes new and alternative ways of being together, which evoke collectivity, anonymity, spontaneity, creativity and plurality of the voices. When we put together the virtues that the occupation of the public square gave to the politics and the ancient tradition of folk humour, we noticed an overlap between them. By adapting Gole's conceptualisation of the public square movement to the realm of humour, this study defines the language of the Taksim Gezi Park movement as the public square humour (Gole 2013). To explore the analogies between the ancient oral humour tradition and contemporary resistance humour, this study focuses on the conversational humour forms. According to Attardo, conversational jokes are improvised and so occur in less predictable and less organised ways (Attardo 1994: 296). Therefore, situational or spontaneous forms of humour, conversational humour can enhance the public square culture with the virtues of pluralism, improvisation and creativity.

The Turkish oral narrative tradition used to be staged in public places such as market places, coffee houses or town squares during festivals or carnivals. Performing in such places requires an ability to integrate the material to the specific venue and audience. For instance, the humorous work of Meddah [public storyteller] depends on his ability to integrate his jokes and mimicking relating to current events with his social and political criticism (And 1979: 156). The improvisation, therefore, requires quick-witted answers and muhavere [conversation] techniques (Tekerek 2007). Thus, the oral narrative tradition formed along with the creation of a great variety of conversational forms such as exaggeration, inverting, parodies of dialectical features, instrumental foolishness and irony (And 1979; Tekerek 2007). Tekerek points out that the oral narrative tradition has the virtue of pluralism as well. For her, mimicking via parody and irony creates pluralism as well as multiplicity of voices and characters in the play or narration (Tekerek 2007: 21).

Besides Ozgen's input on the reinvention of Nasreddin Hodja humour, several studies on the humour of the Taksim Gezi Park resistance exemplify the link between the resistance's humorous language and the usage of the traditional folk humour techniques. The following examples also illustrate the link between the public square humour and the virtues such as improvisation, creativity and pluralism. Dagtas, for instance, insists on the importance of the mimicking as a subversive humorous tool for the Gezi Park protesters. She gives an example of how Erdogan's use of the word capulcu to describe protesters as "looters" turned into a neologism to refer to "fighting for one's rights" (Dagtas 2016: 21). Emre et al. (2014: 6) gave one of the examples of inverting of guzelleme [a poetry writing in praise of a special thing, especially a person] in the folk poetry tradition for the tear gas used by the police to disperse and even injure and kill the protesters. The slogan "biber gazl oley", which means "yay, tear gas!" (this slogan has a connotation suggesting that the person is not affected by, but, on the contrary, enjoys the tear gas); the rhyme "sık bakalım", which means "c'mon, shoot it!" (a rhyme to let the police that the protester does not fear its power and authority); the writing " $b u$ gaz bir harika dostum", which means "dude this gas is awesome!"; and the lyrics "biber gazı bala benziyor", which mean "tear gas is like honey" (Emre et al. 2014: 6). In her analysis on the graffitis of the Taksim Gezi Park, Morva shows the accent on the pluralism created through 
graffiti humour, which brings together different ideological backgrounds of protesters together (2016: 28). "Ne devrim ne seriat sadece saygi" [No revolution, no religious law, only respect!], "Korkma lan, biziz, halk!" [Dude, don't be scared. It's us. The people] and "Merak etme anne onden yurumuyorum beraber yuruyoruz!" [Don't worry mum, I am not at the front, we walk together!] are the examples that she gave in this context.

This study focuses on the emergence of this public square humour in the context of politicians' humour during the elections. How the politicians reacted to the request of certain part of the society to make politics more pluralistic and creative? Although the outcome of the efforts of politicians to catch the new language of the opposition would stay in the context of representative democracy, it is important to investigate the short-term effect of the Taksim Gezi park humour on the humourless context of politics.

\subsection{Twitter: an emblematic medium of free speech in Turkey}

The use of Twitter to discuss politics fashioned by the Taksim Gezi Park protests. According to Caren \& Turkoglu's study, during the protests in June 2013, 660,000 Turkish language users joined Twitter, which was the largest monthly increase in Turkey (2014). Since Twitter played a key role in the self-organisation of tens of thousands of people in the form of massive protest, the Prime Minister Erdogan called it a menace. Henceforth, Twitter is considered as an emblematic medium of the opposition; but also a powerful tool to distribute political messages. The success of Twitter during the protests is also depends on the key features of the medium. On Twitter, every user can publish short message (tweet) up to 140 character to join or start a conversation which are visible on a public message board of the website. The word limit provokes the usage of short, direct and simple language, which creates a sense of face-to-face conversation (Graham et al. 2010). It also inspires the usage of the conversational humour tools for the creation of slogans and short, simple and informative contents. During the Taksim Gezi Park protests tweets recapitulated slogans, catchphrases, jokes, and retweets diffused them to larger publics. In other words, the tweet genre was convenient for the protesters to use their humour and intelligence to display their criticism over increasing suppression of freedom.

Not only did the Taksim Gezi Park protests prove the role of online social networks in political mobilisations, they also showed their role in the democratisation of information. During the protest, in contrast to the position of the traditional media, which prefers broadcasting some nature programs like a documentary on penguins instead of the protests, for many people Twitter became a reliable source of information. This perception got stronger when the major news channels started to use tweets for covering the protests. The government' effort to cut off the Internet during the uprisings also contributed to this view of seeing Twitter as a free medium which the State wants to silence as it did for most of the other media. According to a 2015 survey by the Reuters Institute for the Study of Journalism, among 18 developed nations, urban Turkey ranks first in using social media as a news source (67\%), and using Twitter as a news source (33\%) while it ranks last in trust of the media (Reuters 2015). On the other hand, the extensive usage of Twitter by the Prime Minister Erdogan with 9,250,000 followers displays the dilemma of the political power between the efforts to control social media and embrace its communicative role.

The literature on the political potentials of social media also indicates that Twitter massively increases the amount of information available to voters and party activists. The bestknown set of arguments emphasises its role for the political competition. It potentially allows previously marginalised or even new parties to emerge and compare with established players or perhaps facilitates non-party or even anti-party political movements (Chadwick, 2006:18). In our case, we can argue that it helped the HDP (The People's Democratic Party), which is 
marginalised by the mainstream media as an ethnic party, to reach out to non-Kurdish voters as well as advertise its financial support campaign.

As a part of the tight situation of the freedom of speech in Turkey, the government consistently shows an effort to limit or control the Internet since the law no. 5651 Regulation of Publications on the Internet and Suppression of Crimes Committed by Means of Such Publication was approved in 2007. The law targeted the problems of pornography and drugs on the Internet but was also widely used politically to block the opposition websites and the anti-government social media contents such as websites supporting the extreme left or the Kurdish nationalist movement. In the case of elections between the years 2014-2015, it was used particularly to stop the circulation of the content related to the corruption videos and tape recordings about the Prime Minister Erdogan and some of the ministers of his cabinet. Therefore, we should consider the effect of State surveillance on Twitter users in terms of selfcensorship as well. However, the data on the increase of the usage of Twitter in this period does not prove this point of view. The first two-months of 2014 have seen $45 \%$ more new Turkish language accounts than the first two months from last year (Caren \& Turkoglu 2014). The low level of trust to traditional media and the deficiency of alternative channels played a critical role in the growth of Twitter in Turkey. The key features of the tweet format also enable more participatory forms of talking politics against the oppressive techniques of the State. And the language of humour becomes an important vehicle of information transmission in these oppressive situations (Al-Momani et al. 2016: 5110). The selection of tweets as an object of the study allows us not only to see how politicians change their narratives via the adoption of the public square humour; it also shows public reaction to these changes.

Twitter became the symbol channel of the Taksim Gezi Park movement and played a crucial role in transmitting political messages to the opposition. It also enhanced the communication between professional politicians and people by creating alternative ways of dialogue during the elections. Before giving information about the political actors involved in the election campaign in the post-Gezi Park period, I will dedicate next section to the political humour tradition in Turkey.

\section{Political humour in Turkey}

The language of humour used against the oppressiveness of the political authorities has deep roots throughout the history of Turkey, beginning from the oral tradition of humour in the Anatolia with Ezop fables, Bektasi and Nasreddin Hodja anecdotes, Ortaoyunu, and Meddah performances in the carnivals and celebrations in the Ottoman era, the lampoon Diyojen, Markopasa in the early Republic days then cabaret shows and satirical short stories of Aziz Nesin and humour magazines Girgir and Limon published in the 1980s and 1990s. According to Gurkas, the tradition of political humour constitutes a rebellious voice disguised under the instrumental foolishness and spontaneous cleverness of the everyman (Gurkas 2008).

The most prominent example of the humour against the authoritarian political power in the recent history of Turkey was the Markopasa of the late 1940s. As a satirical humour magazine, it criticised mostly the rule of single party of Ismet Inonu (Cantek 2001). It expressed the people's discontent through an unusual humour and fresh language, directly taken from oral speech (Mat 2010). By facing difficulties for publishing and distributing the issues, the magazine sold up to 70,000 copies. Its co-founders and principal authors Sabahattin Ali and Aziz Nesin were persecuted and imprisoned several times.

Modern weekly humour magazine tradition started with the apparition of Girgir in 1972. Soon it became a phenomenon of the era between the years 1970s and 1980s. Tunc defines the magazine as a sociological phenomenon, which reflects the fracture of identity caused by the 
peasant migration by producing numerous cartoon characters and comic stripes (Tunc 2001). During the military coup in 1980 and the government of Turgut Ozal, the humour of Girgir became politicised (Tunc 2001). Since then, the cover and the two consecutive pages of the humour magazines are dedicated to the political issues. After Girgir's success, in 1990s numerous humour magazines mushroomed, e.g., Hibir, Limon, Leman, Penguen, Uykusuz, etc. Tunc stresses that Girgir's political attitude formed through the defense of the secular, contemporary, westernised nation in the same way of its founder Ataturk (Tunc 2001: 250). Beginning from Leman, the new generation of humour magazines became more interested with the representation of cultural life through cultural divisions and consumption tastes (Oncu 2001). But they still continued to produce political cartoons for their covers and first pages. For their political attitude, Tunc's definition is still valid. On the other hand, the Taksim Gezi Park protests awaken Islamic communities' interest in humour magazines as well (Colak 2016). In addition to the only humour magazine with Islamic tendency CafCaf, several other magazines appeared, such as Hacamat, Puff and Cins. As the first of its generation CafCaf was founded in 2005 and has 9,000 circulation figures (Ozgur 2012:1). Upon the analyses of CafCaf's political humour, Colak points out that the magazine changes its direction from the defense of Islamic virtues to protect of the power of the AKP (Colak 2016).

Another branch of political humour is coming from the improvisatory theatre tradition of Turkey. During the 1950s and early 1960s, the cabaret theatres, which founded by private companies, constitute the major source of political humour. The Muammer Karaca Theatre was the first example of the genre. In this tradition the scripts are usually used more as an outline upon which the actors superimpose their own inventions in attempts at political and social satire, social oddities, topical comments and pungent jokes (Rubin et al. 2001: 859). In the 1990s Devekusu Kabare (Ostrich Cabaret), the Ulku Ozcan Theatre and the Levent Kirca Theatre were the three major companies working on this genre. In their cabaret sketches, Alasya and Akpinar mostly made fun of those political leaders who were known with their tolerance to humour. When they performed live, they often sold out sports arenas setting up to 7,000 people (Rubin et al. 2001: 859). During the 1990s Levent Kirca adapted his theatre to television by creating weekly satirical sketch called Olacak o kadar, which aired on several TV channels for twenty-two years. During these years, Kirca lampooned not only political leaders but also the military, police torture and women's rights.

In parallel with the interest in humorous popular culture, the political leaders such as Suleyman Demirel, Erdal Inonu and Turgut Ozal showed positive attitude to use humour in their speech. Demirel was himself a powerful orator with the ability to make use of humour to reach large groups of people. He produced many memorable quotes throughout his political life. One of his famous quotes was an answer to the reporter's question about the rising tension between Greece and Turkey concerning the exercise of sovereignty on the waters of the Aegean Sea in 1975: "The Aegean is not a Greek lake. The Aegean is not a Turkish lake. Actually, the Aegean is not even a lake" (Hurriyet). With the help of humour he managed not to heighten the tension and keep the situation ambiguous. For this generation of politicians humour used to be a rhetorical tool to heighten or to soften the political tension and a powerful weapon to criticise the opponent. As Suleyman Demiral once claimed "Humour is like a punch, you can't know who will hit or when" (Hurriyet). During the Taksim Gezi Park protests, the image of politicians who used humour as well as tolerated it generated many comparisons between the Prime Minister Recep Tayyip Erdogan's reactions and previous leaders' (van het Hof 2015:46). When we consider the countries such as United States, which has a tradition of the annual White House Correspondents' dinner since 1922, Turkish politicians' account on the political humour seems limited. According to Egilmezler, the Prime Minister Erdogan and his Justice and Development Party (AKP) have rarely used humour to smooth the often times hard edged 
of political debate; instead they tapped into a psychology of victimisation to bond with the poor and socially excluded conservative masses (Egilmezler 2014).

In recent years, even though, there has been a lack of interest to humour from the side of political leaders, the humorous popular culture continues to enlarge by the new instruments like Internet humour and stand-up genres. In this context, the Taksim Gezi Park humour created a distinctive moment in the tradition of political humour with a taken-for-granted attitude toward secular and modernist norms. The presence of anti-capitalist Muslims next to the feminists at the Taksim Gezi Park created the public square humour, breaks down the thick wall of prejudices on political identities and opens up a space for pluralism, improvisation and creativity.

As I will try to explain in the following sections, this article focuses on the twenty-five months period from the first days the protests (27 May 2013) until the election of 7 June 2015 in Turkey. After giving information about the setting, and method of the analysis, the article will trace the reproduction of the public square humour by professional politicians in the milieu of Twitter.

\subsection{Three elections in 25 months}

Before the Turkish parliamentary election of 7 June 2015, two more elections were held in Turkey: the Municipal election on 30 March 2014 and the Presidential election on 10 August 2014. In fact, the results of the parliamentary election did not last long. Since a coalition government could not be established in the Parliament, the president made the announcement of a snap election dated three months later, in November 2015. This study does not embody that period since the violence triggered after the June 2015 elections made it impossible to conduct a democratic political campaign ${ }^{1}$.

The Taksim Gezi Park protests constituted a challenge for politicians during the twentyfive months long election period to catch up the rising language of humour as well as attract middle class votes to their side. As a result, the agenda of the opposition parties focused on the demand of freedom and participatory democracy voiced by the Taksim Gezi Park protesters. The debates around these major themes were diversified to minor issues such as: the engagement of Erdogan in social engineering by telling people how many children they should have, that abortion is murder and so on; the corruption allegations against the government and Recep Tayyip Erdogan's family, the restrictions on the freedom of expression and the future of the peace process between the PKK (Kurdish Workers Party) and the government.

The parliamentary election of June 2015 produced two critical results especially for the AKP and the HDP (People's Democratic Party). It ended the single party rule of the AKP, which has been in power since 2002. And for the first time a party that mainly represents the Kurdish population ran in an election as a party and won seats in the parliament. The Kurdish dilemma, therefore, stays at the locus point of elections whether they open up themselves to the large sections of the urban middle classes (Saadetyan 2015; Wallerstein 2013) or closed up Islamic sphere under the established politics of the AKP (Kemahlioglu 2016). The Kurds in Turkey have been struggling, ever since there was a Turkish Republic, to obtain the right to autonomous structures and the use of the Kurdish language. And in the last forty years, they have been organised within a movement called the PKK (Kurdiah Workers Party), which engaged in military action to pursue its objectives. After the leader of the PKK was imprisoned, the PKK decided to allow diplomacy to work. The HDP played an active role for this process of dialogue by cooperating with the government. That's why among all different political agents, the Kurdish movement was reluctant in their participation in the Taksim Gezi Park movement at the beginning even though one of the deputies of the Kurdish political party Sirri Sureyya Onder was at the Park from the very first day of the sit-in. According to Wallerstein, 
the hesitation that the Kurdish movement felt during the protests constitutes a dilemma of the Kurds between Erdogan and his supporters, who intend to pursue the peace process and some segment of the secular left, who are a mainstay of anti-Erdogan uprising in Taksim Square (Wallerstein 2013: 32). However, the Kurdish movement managed to seize the opportunity to open itself up to large sections of Turkish youth and Turkish left in the wake of Gezi protests (Vatikiotis and Yoruk 2016: 7). According to Saadetyan, the HDP leader Demirtas' usage of humour played an important role in reaching different sides of the oppositions (Saadetyan 2015). Hereby, by adopting this new language Demirtas raised the HDP (People's Democratic Party) votes by making them more than double the historical Kurdish vote in the June 2015 elections. To understand better the Turkish political scene, brief information about the major political parties is given below.

\subsubsection{People's Democratic Party (HDP)}

Established in 2012 as the political wing of the Peoples' Democratic Congress, a union of leftwing political organisations, the People's Democratic Party is situated on the left of the Turkish political landscape. People's Democratic Party (HDP) is the eighth successive Kurdish political party in Turkey. All of its predecessors except BDP were outlawed by the Turkey's Constitutional Court ${ }^{2}$. The HDP describes itself as an environmentalist and anti-capitalist party that aims to improve workers' rights. It stresses the importance of equality between men and women. The party's leadership is composed of two co-leaders, Selahattin Demirtaş and Figen Yüksekdağ.

\subsubsection{Justice and Development Party (AKP)}

The AKP emerged in 2001 and positioned itself as the moderate wing of political Islam, while pursuing an orthodox neoliberal, pro-EU and pro-NATO line. The party was led by the former mayor of Istanbul, Recep Tayyip Erdogan until 2014. The AKP portrays its rival, CHP (Republican People's Party) as the party of the economic, social and military elites (Yoruk \& Yuksel 2014:109). Without leaving the traditionalised pattern of nationalism in centre politics, AKP managed to take steps toward the resolution of the Kurdish issue under a wider framework: Sunni Islam (Keyman 2007:215).

\subsubsection{Republican People's Party (CHP)}

CHP was established by Kemal Ataturk in 1923 and it kept control of the government until the 1950 elections as an authoritarian party (Schlager \& Weisblatt 2006 : 1375) The CHP is traditionally regarded as the party of the ruling elites of the founders of the republic although the party has not ruled for decades. By contrast to AKP, CHP mostly relies on an urban middle class electoral base. Under the new leadership of Kemal Kilicdaroglu, the party has become less nationalistic and more social democratic (Cingi 2011:4). CHP constructed its opposition around the marginalisation of economy and foreign policy during its electoral campaign.

\subsubsection{Nationalist Movement Party (MHP)}

This ultranationalist party under the charismatic leader Alparslan Turkes remained a minor party, only influential in alliance with some other party of the right throughout the 1980s and 1990s. After the death of Turkes in 1997, Devlet Bahceli was elected as the leader and he moderated the neo-fascist discourse to some extent. Its nationalist agenda has led the MHP to strongly oppose President Erdogan's peace process with the PKK. 


\section{Method}

The analysis starts from the close observation of what professional politicians posted on their public Twitter account over the twenty-five months. We then examine those materials by their usage of conversational humour forms such as irony, parody, neologisms, rhymes and proverbials (Dynel 2009) to create possible connections with the language of humour of the Taksim Gezi Park protests.

\subsection{Data collection and quantitative analysis}

The data of the study gathered from tweets of four major political parties' leaders and two additional candidates of each party who have the most followers in Twitter. 'Following' in Twitter is a form of personalisation, which allows users to see messages from the people they follow on their main page. For the AKP, we selected the President Recep Tayyip Erdogan since he continued to be involved in the AKP's campaign after he had been elected in the first presidential election in August 2014. Although the institution calls for a non-partisan president, Erdogan organised rallies in which he campaigned for the AKP (Kemahlioglu 2016: 453).

The dataset we gathered composed of these Twitter user politicians listed below (with number of followers in parenthesis):

- The HDP: Selahattin Demirtas $(1,570,000)$, Figen Yuksekdag $(454,000)$, Ertugrul Kurkcu $(336,000)$.

- The AKP: Ahmet Davutoglu (5,210,000), Recep Tayyip Erdogan $(9,250,000)$, Mehmet Simsek $(1,770,000)$.

- The CHP: Kemal Kilicdaroglu (4,140,000), Muharrem Ince (2,370,000), Safak Pavey $(1,610,000)$.

- The MHP: Devlet Bahceli $(2,730,000)$, Meral Aksener $(890,000)$, Oktay Vural $(868,000)$.

We collected a corpus of twenty-five months of public tweets of twelve candidates from four major political parties (from 27 May 2013 to 7 June 2015) through Twitter's REST API ${ }^{3}$. We used Python programming language ${ }^{4}$ with tweepy library ${ }^{5}$ to fetch data from Twitter.

Twitter REST API only provides the most recent 3,200 tweets of a user. This number was sufficient to cover the time range we wanted to investigate for seven leaders, but in the case of the leaders who were more prolific users of Twitter we had to use Twitter search. Twitter search allows searching all tweets but is not exposed as an API and results are only available as web pages.

To process Twitter search results, we downloaded the result web page (which is not restricted in time range) as HTML and parsed the tweet IDs. REST API supports downloading tweets by ID, which we used to obtain tweets and related metadata for the five remaining leaders.

After collecting the tweets we used various python APIs and small amount of custom code to convert tweets and some of the associated metadata (such as retweet/favourite counts) to Excel sheets for analysis. We also calculated some aggregate statistics:

1. Most popular tweets of each user investigated (ranked by sum of retweets and favourites): "Retweeting" is a way of sharing a message by someone else with some comments to people who follow you. It is a common way to propagate messages in Twitter. "Favourite" allows users to save messages they particularly like in a personalised list.

2. Frequency of word use per user. We filtered out some common words in Turkish that are not relevant for analysis (equivalents of "one", "and", "this", "for", "too, etc.) and looked at 100 words from each leader. 
3. Frequency of bigrams (pairs of words that occur next to each other). We also filtered common irrelevant words and looked into most common 20 bigrams for each leader.

The amount of tweets we investigated made a total of 23,591 contexts, and with the extra metadata our dataset was serialised to a dataset of size $237 \mathrm{MB}$.

\subsection{Manual qualitative analysis}

Using the data collected, we did a manual analysis of the Twitter usage. This includes the following actions:

- We read the full set of tweets to get an understanding of the Twitter use by leaders in this period.

- We then investigated the use of the top common words (found in the quantitative analysis) in the context of tweets.

- We looked at the most popular tweets of leaders and tried to attribute the reasons to their popularity (which we discuss in more detail below).

- Finally we correlated these tweets with tweets from other leaders to reconstruct the conversation.

The qualitative analysis is based on the detection of the usage of conversational humour techniques of the politicians. Upon the definition of the public square humour, the present study investigates the presence of the three virtues (pluralism, creativity and improvisation) in the tweets by examining the tweets by the usage of conversational humour tools, namely, irony, parody, neologism, rhyme and proverbials. Through the problematic of the study, we try to answer these questions:

- Which narrative tools do the politicians use?

- Is there a link between the popularity of tweets and the usage of the humour?

- Which politicians adopt the Taksim Gezi Park movement's language of humour with its virtues of pluralism, improvisation and creativity?

\section{New language of the opposition: The humour in Turkish politics}

We have investigated the usage of the public square humour through its reflection in the Twitter sphere. We considered all tweets by the twelve most popular politicians during this period. Upon the analysis of the most popular twenty tweets of the twelve politicians during election campaigns, we argued the possible adoption of the virtues born at the public squares.

\subsection{The most popular tweets of the leaders}

In the whole corpus of the data of 23,591 tweets in the period of 25 months, we first looked at most favoured tweets. Among them, Erdogan and Demirtas had the majority of the popular tweets: each had eight tweets in the top twenty. Bahceli had two tweets in this list and Davutoglu and Kilicdaroglu had one each.

Recep Tayyip Erdogan's most popular tweet was: We only bow down in ruku' ${ }^{6}$ This tweet was also the most popular tweet of our twenty-five month long data. It was a reference to another popular tweet he made: We will continue our struggle while surrendering to the fate above fates and we will not bow down. We only bow down in ruku and nowhere else. This tweet was 20th most favourite tweet of the analysis corpus as well. Ruku is part of the daily Muslim ritual, where one bends down after reciting prayers during the Sunni Islamic prayer namaz. The references to the religious practises help him to wrap up his political history with the announcement of challenge coming from opponents against the unity of his co-religionists. 
This point of view allows us to see the major schema of the discourse of Erdogan and thereby his definition of "we" as the Sunni-Muslim population. Just after Erdogan's speech at the Presidency Palace referring to the government as the only interlocutor of the Turkish-Kurdish peace process by questioning the HDP with his phrase "Who do you think you are?" the most popular tweet of the leader of the HDP Demirtas appeared in Twitter. It was the question he addressed to the Prime Minister Recep Tayyip Erdogan: You asked me who I was, shall we get acquainted $?^{8}$ When we add the fact that $0.90 \%$ of Erdogan's tweets starts with the word "we", Demirtas' misinterpreting the question becomes more meaningful and offers boisterously naive counterpart of the 'we' discourse of the leader of the government. His question was an attempt to not only to underline the religion-centric, pervasive and totalitarian tone in Erdogan's language, but also to use irony under the guise of naivety and optimism about opening a dialogue in a climate of political closeness created primarily by the discourse of "we". The deliberative misinterpretation of the Erdogan's ironic question is also a humorous attempt, which helps Demirtas to retrieve his political position as a representative of the opposition in Turkey as well.

The binary opposition between ordinary human and the elite, naive and swindler, poor and rich stereotypes provides the comic element that oral tradition of folk laughter often uses. Demirtas' naive question mark symbolises therefore the instrumental foolishness of the narrator in the folk tradition of humour, who pretends to misunderstand the prime minister's emphasis on the word "we" and the totality of the voice of the power as well as the pessimistic political climate. The naive question of Demirtas revisited the traditional folk laughter figures like Keloglan or Ibis in Ortaoyunu or Tuluat characters that use "simple mindednesses" in line with Bakhtin's definition as a device of misunderstanding the mechanisms of oppression and the irrationality of power (Bakhtin 1984:164). On the other hand, the second most popular tweet between twelve politicians' 23,592 tweets and Devlet Bahceli's most favourite tweet could be interpreted as a rise against this pessimistic climate diffused in the society. He catches the desperation but reflects it in an ironic question form: Won't we ever laugh? Won't we ever have a happy and peaceful day? ${ }^{9}$ His second most favourite tweet also constitutes an example of this narrative about the political context of the country: We are tired of being sentenced to darkness in daylight. ${ }^{10}$. In parallel with Erdogan, Bahceli uses irony as a discursive tool, but instead of highlighting group membership he expresses his affective state of mind. His irony also arises from the mismatch between the current context and his political proposition (Dynel 2009). As we can see in these tweets, even though irony is one of the forms of conversational humour, the ironic utterances do not always overlap with humour (Dynel 2009). However they fulfil several important communicative goals, such as heighten or soften criticism, elicit emotional reactions, highlight group membership and express affective attitudes (Kao \& Goodman 2015).

The co-leader of the HDP Yuksekdag's most popular tweet was Goodnight everybody. You were magnificent! ${ }^{11}$ She shared the tweet after the official announcement of the results on the night of the general election. Her emphasis on solidarity and her usage of the direct and simple language is related to her activist political background. She had pursued politics in the feminist and socialist organisations, and before she entered conventional politics, she was the former leader of the Socialist Party of the Oppressed, which merged with the HDP in 2004.

Davutoglu's most favourite tweet in the twenty-five months of analysed data was his tweet Alhamdulillāh... ${ }^{12}$, an Arabic phrase meaning "Praise be to God". Within all tweets of twelve politicians, Davutoglu's Alhamdulillah stayed in the fifth place. The tweets of Davutoglu and Erdogan can be arguably considered a key to understand the AKP's method to mobilise religion to reconstruct politics. As Tugal puts it briefly, the Muslims of the AKP were no longer considered Islamists but conservatives integrated in capitalist liberalism without leaving the nationalist discourse thanks to the passive revolution (2008: 75-6). 
The CHP leader Kilicdaroglu's most favourite tweet is Persevere against the twitter ban, tweet for freedom ${ }^{13}$. Seven days before the municipal elections, the government had declared that they restricted access to Twitter. The Internet users quickly found out new ways to circumvent the block and they posted almost 2,500,000 tweets - around 17,000 tweets a minute (Letsch 2014). Kilicdaroglu's tweet can be interpreted as a counterattack coming from the freedom sphere against the Twitter ban by the authoritarian government. In particular, the six tweets of Erdogan that we have looked at, all attacked the major opposition party, CHP and the prohibitions made under its one party-rule between the years 1923 and 1950. In these tweets Erdogan underlined the regulations designed for the purpose of the withdrawal of religion from public life.

In the 25 months period of analysis, the keyword "ban" appeared 95 times. Except for Erdogan, Davutoglu and Simsek's 12 tweets, the rest come from the opposition criticising the Prime Minister Erdogan's attacks on freedom of expression and association (76) and the law restricting sale and advertising of alcohol (7). Forty six tweets accused Prime Minister Erdogan of stifling information incriminating him in corruption scandals. Demirtas, Yuksekdag and Kurkcu's 16 tweets are not focused on corruption accusations but on the ban on celebrating 1 May in Taksim public square and the government's prohibition of strikes (nine tweets of three HDP politicians) as well as the demand to outlaw tear gas usage by security forces and the criticism of abuse of rights during and after the Taksim Gezi Park protests (seven tweets). In the "ban" context, the unique tweet of Demirtas is: It is said that you banned Gezi Park from entering 2014, is this true Mr. Governor? @ Valimutlu14. Demirtas's tweet on the New Year's Eve of 2013, which is the year of the massive resistance against the government, is a remark for the mindset of the Governor and his government as well as a reminder of the moments of freedom experienced in the Gezi Park. By impersonating the Taksim Gezi Park, he underlines the irrationality of the decisions of the Governor and his government. In this way he draws a caricature of the Governor by exaggerating his lack of ability to act rationally. As And describes for the folk oral narration, Demirtas's tweet uses humour by setting it against the negativity in life and nourishing improvisatory techniques of caricaturization and exaggeration accompanied by a direct and cheerful language (And 1979).

\subsection{The "shoe" issue}

The stereotypical characters and the binary oppositions derived from their contrasting positions constitute one of the important narrative tools in traditional Turkish folk laughter. The two characters appearing most frequently in popular Turkish folk tales are Kose [cannot grow beard] and Keloglan [bald boy]. Keloglan is a sympathetic peasant boy, stupid, naïve in some tales, yet he is the one who always wins in the end, making his fortune or succeeding by ruses and cunning. His counterpart Kose is a more negative type. He is not sympathetic and he is a trickster. Depending on the story he acts treacherous, cruel and vicious, and sometimes has supernatural powers. He is the one who injures people without remorse; he is an intriguer who lacks any human feeling (And 1979:159). In the presidential campaign the stereotype based on the binary opposition of a naive man and a swindler politician constituted the subtext of the campaign of the opposition in reference to one of the contemporary examples of Kose, Zubuk character. Zubuk "the swindler", a humorous character who watches over his own interests, presents a parody of political degeneration. The character was developed from the same named short story Zubuk written by Aziz Nesin in 1961 and adapted to cinema in 1980. Since then the film and the character Zubuk have been integrated in Turkish popular humour as a powerful representation of the corruption of bureaucracy as well as moral degeneration of the politicians and regime (Turker 2006). The usage of the religious references for the political interests and the naivety of everyman against the swindler politician Zubuk is the main axle of the story, 
besides the critique of the populist politics with references to actual political parties and politicians of the era. The comparison of Zubuk and Erdogan therefore provides a humorous framework to criticise AKP.

Before the parliamentary elections the police arrested the sons of three cabinet ministers on 14 December 2014. They found shoe boxes filled with four and half million dollars in the house of the son of the minister of internal affairs and the director of Halkbank. Thereafter "shoe box" became the new word of the corruption in the language of politics. The utterance of the words, "Zubuk" and "shoe box" worked as a sufficient keyword to remember the corruption accusations about the Prime Minister Erdogan and some of the ministers of his cabinet. Even though in their public speeches the opposition leaders of CHP, HDP and Oktay Vural from MHP uttered the word Zubuk for defining the politics of AKP, in Twitter we only find the reference of the "shoebox".

Oktay Vural created a hashtag \#CorruptionoftheCenturyFromShoeboxParty (\#AyakkabiKutusuPartisindenAsrinYolsuzlugu) and has used this reference to "Shoebox Party" instead of the word AKP since then (Vural 21 December 2013) ${ }^{15}$. His neologism was accepted eagerly by the politicians. Out of 81 tweets containing the word "shoebox", Ince had 40 tweets, Vural 23, Aksener six, Kilicdaroglu four, Demirtas two, Yuksekdag two and Pavey one. The wordplay used in these tweets provides the satirical component for the oppositional discourse especially for Ince (CHP) and Vural (MHP), who built up their campaign on the moral corruption of the AKP. Within the first twenty favourite tweets of twelve politicians, the most popular tweet belongs to Ince: Put your votes into the ballot box not the shoe box ${ }^{16}$. The latter came from Aksener: What happened to police placing the money found in the bedroom and the shoebox? If the police don't own the money which will be returned with interest, Call the cops are Thieves ${ }^{17}$.

Demirtas and Erdogan remain silent about the shoebox issue in Twitter. Among 81 tweets, only the tweets of Demirtas and Erdogan contain the word "shoe" but from a totally different angle. Erdogan's tweet: They weren't entering the mosque with shoes on and drinking alcohol. On the contrary, they were shoving the ones entering the mosque with shoes on and drinking alcohol to the sea ${ }^{18}$. Erdogan is comparing the Ottoman soldiers fighting against the Allied Powers during the First World War and the youth at the Taksim Gezi Park protests. The tweet is also a reminder of one of the most controversial accusation of Erdogan and his supporters against the protesters. During the protests, the videos about a group of people that ran into the Dolmabahce Mosque to escape from the tear gas cannon of the police became a hot topic of discussion. Erdogan and his supporters raised the subject in order to change the direction of the public discussion and create a negative image of the protesters. Once again in this tweet we can see Erdogan's political position at the intersection of the nationalism and the Sunni-Islam vision. It also helps us to see the establishment of the symbolic categories of this ideology of the political power by identifying the binary oppositions he made between west/ern and east/ern; irreligious and religious; cursed and holy; invader west and defensive east.

One of the two tweets by Demirtas about the "shoe" discussion took the same perspective: I wonder if they entered the tunnel with shoes on $^{19}$. The phrase has the same naive voice and is based on the misunderstandings of the narrator. It is again a simple-minded but tricky question; it uses the same logical scheme of Erdogan for making a much more controversial issue visible: the escape of eighteen Kurdish detainees from the prison in Bingol by digging an eighty-meter long tunnel (Hurriyet 25 September 2013) ${ }^{20}$. The tweet can be considered as an example of the spontaneous cleverness of tradition of Turkish folk laughter under a deliberate misunderstanding of the dominant logic. Demirtas thus uses the mechanism of parody coming from Nasreddin Hodja's humour tradition and touches upon a very critical point by adapting of the same category of thought invented by the state for evaluating its opponents, or more precisely, for evaluating the "terrorists". 
The summary of Erdogan's response as the head of the state could be as follows: without showing any interest in what and why is happening classify the event by populist labels of nationalist and religious discourses in search of legitimizing state authority. On the other hand, the criticism underlying Demirtas' humorous comment shows us the identification of the Taksim Gezi Park experience as another example of the violence of the State against the resistance.

The humour in the Demirtas' tweet, on the other hand, illuminates the connection Kurds developed during the protest movement spreading over the country. According to Elisabetta Costa, who conducted an ethnographic study on the use of social media in the Southeastern regions of Turkey, Kurds in the southeast region did not identify with the protesters' because since "They saw it as a struggle of middle class urban Turks, who were rebelling against the status-quo" and finally experiencing the violence and the brutality of the State that the Kurds had been suffering for so many decades" (2016:151). But the Demirtas' tweet shows us how the dialogue between the protesters in the Taksim square and the Kurdish population has been built up in the form of ironic interrogation of the apparatus of State domination. One of the banners at the Taksim Square points it out as well: "Do you understand now why Kurds put two antennas on top of their houses". Until 2008, it was illegal to broadcast in Kurdish language in Turkey. And the Kurdish population used to have satellite antennas to be able to watch Kurdish television channels and get the news and information about the PKK. At the beginning of the Taksim Gezi Park resistance the traditional Turkish media mostly ignored the presence of the protesters, and the people used alternative media channels such as Twitter and Facebook to get information. Here, the analogy created through the similar experience of the State control, which prevents the people to get the news. Even though Demirtas' and Erdogan's previous tweets weren't popular on Twitter, they are representatively important to understand the differences in thought processes of two political actors: one representing the language of the government and one side of the opposition.

\subsection{The humour in the most popular twenty tweets}

In addition to the analysis of the most popular tweets, we try to detect the language of humour in the most popular twenty tweets of the politicians. The following tweets will allow us to argue on the usage of the conversational humour forms by the politicians. Kilicdaroglu's ninth most popular tweet exemplifies the usage of irony and exaggeration: Even Hitler did not think of turning a city into a gas chamber ${ }^{21}$. He continues to speak in the "freedom" frame on behalf of the democratic norms, but this time he linked the pepper gas used in the Taksim Square with Hitler's gas chambers. The exaggeration is based on the binary opposition between fascism and democratic forms of the government. The reference to Hitler stresses Erdogan's authoritarian tendency and anti-democratic reactions against the protesters at the public squares.

Another example of the usage of irony is Simsek's tweet on Demirtas' comment on the Taksim Gezi park protests: Demirtas: "People went out to the streets everywhere. Violence was never used anywhere." I guess aliens looted, burned and killed people ${ }^{22}$. Simsek uses humour to mock the naiveté of Demirtas. But his ironical elaboration of the simple mindedness shows a contrast compared with that of Demirtas'. While Simsek ridicules the naïve, Demirtas shows pride of it. The exaggeration and irony is used by Aksener's seventeenth popular tweet as well: During his mastery period, the flag was lowered in the motherland, consulate got invaded, and our people were taken hostage. Allah save us from his "grand mastery" period" ${ }^{23}$. Aksener, in her tweet made an ironical critic of events, which the AKP government presented to them as an achievement. 
Yuksekdag's tweet commenting the results of the 7 June 2015 election provides an example of the humour based on the word-play: We got tired but it was worth it. We don't need the light bulb anymore... The morning is coming. Bandista - Sun Is Rising Up Again ${ }^{24}$. Yuksekdag underlines her optimism over the results of the 7 June elections by defining their success with the metaphor "rising of the sun", which reaches to the point that we don't need a light bulb, the symbol of the AKP.

Kurkcu's second most popular tweet arises from his spontaneous cleverness used for the production of improvised humour: There is nobody from AKP in TBMM (Grand National Assembly of Turkey). It is said that they went to get their kids from school before Zekerriya ${ }^{25}$. Zekerriya $\mathrm{Oz}$ was the prosecutor of sensational investigations in the past few years including the corruption operation in which the son of the minister was arrested. Kurkcu made a quick wit interpreting of the atmosphere of the parliament on the day the corruption operation of the police started. Kurkcu like a field reporter was updating his followers about the situation in the parliament on such a critical day. His sarcastic tweet expresses political criticism via making fun of AKP and its deputies involved in the corruption allegations. Sarcasm refers to an aggressive remark that carries humour (Dynel 2009). It is also defined as the negative type of irony, that is realised when a negative evaluation is realised via a positive statement (Dynel 2009:1289). Kurkcu made a positive statement about the deputies who are taking care of their kids like responsible fathers; but he mentions how they are responsible of the corruption as well.

Another humour technique used often by politicians of MHP is the rhyme and proverbials. Aksener's most popular tweet THERE IS GOD, BUT THERE IS NO CONCERN ${ }^{26}$ exemplifies the humour arising from an invention of proverbial. In this way, she criticises the usage of the religious discourse of AKP for hiding its political responsibilities. Vural's tweet: recite bismallah, vote for $\mathrm{Ekmel}^{27}$ constitutes the usage of rhyme (besmele - ekmele in Turkish) for the creation of humour as well as a slogan easy to remember to attract the attention of the voters. The leader of MHP Devlet Bahceli's tweet: You would build bridges in places with no river; saw seeds in sand, seeds of discord in mortals. You would call haram helal, reality lies; because you are the candidate Erdogan ${ }^{28}$ is an example of traditional political satire made by rhymes to underline ironic situation and wrong political decisions of his adversary Erdogan.

Demirtas's eight tweets were ranked among the first 20 most popular tweets of the 25 months long period of analysis. He wrote the following tweet '9:) furthermore I love you all 'sapsik's, including the ones that heavily criticised $m e^{29}$ which uses narrative tools of the popular humour as well as twitter language in which '9:) means a smiley and funny face. He adopts the direct language, and uttered an informal word sapsik, which is taken from the youth popular culture to describe cute but confused looks in the shared photos of people or pets in the social media. His connection with the youth culture and tolerant approach against the oppositional ideas represents his different approach to humour. He prefers laughing with the audience instead of putting himself aside and makes oppositions' ideas the subject of his humour. By adopting their language, he invites the audience to participate the production of humour as the traditional folk storytellers do. After the bombing attack at his Diyarbakir rally, he gave another example of his directness and optimism by answering the violent attack with a tweet we will still WIN! ${ }^{30}$. He added the photo of Yilmaz Guney while he was holding the Palme d'or at Cannes festival in 1982. Guney represents a powerful image in the collective consciousness of the Turkish people as a strong figure of the victory of the poor. This tweet and his optimistic attitude became very popular and was the 9th most popular tweet. One day before the parliamentary election he tweeted the fifteenth most popular tweet: If HDP does not happen, they will make the man sultan. If HDP happens we will make the sultan man. ${ }^{31}$. In this tweet Demirtas speaks more directly and uses word play to stress his party's political role in the establishment of the democracy. In the same framework, he wrote the following tweet on 
the day of the election (seventeenth most popular tweet): May it be easy for all democratic observers of the people. I can't tell the party in my heart due to the election prohibitions, but I wanted you to know it is $H D P^{32}$. Once again Demirtas uses the rules and the ruler (as he did in the previously mentioned tweets) as the principal comic elements of his humour. His irony based upon the misunderstanding of the context or rules of the authority under the guise of the naiveté of a layman is similar to Keloglan's. In doing so, he became a contemporary version of Keloglan who is a sympathetic and naïve peasant boy, and who always wins at the end.

\subsection{The catchphrases}

Examining the humorous tweets for the development of a subversive opposition in Bakhtinian sense, we also need to find the basic words of the dominant political language, which the humour will destroy or demystify. For this reason we tried to find the most frequently uttered words of the tweets to reach out to the language of the leader of AKP, which has evolved throughout the twelve years long one-party rule. From this perspective, we searched for the most uttered words and successive word pairs in the tweets of the leader of AKP, and then the President of Turkey, Recep Tayyip Erdogan. Since our corpus of data is too large to analyse in individual tweets, we tried to identify the keywords, labels, etiquettes or catchphrases without forgetting the possibility of certain loss of meaning.

Upon an analysis of the tweets by the frequency of the most uttered single words, we found that the following ten words are the most common words in Erdogan's tweets: biz [we], Turkiye [Turkey], degil [not], bugun [today], yeni [new], kadar [till], her [each], millet [nation], baskan [president], belediye [municipality]. The analysis of binary word groups in his tweets gave us parallel results such as: belediye baskan [municipality mayor], baskan adayimiz [our mayor candidate], yeni Turkiye [new Turkey], Turkiye yolunda [on the way of Turkey], miting [rally], $A K$ parti [AKP written spoken style], buyuksehir belediye [metropolitan municipality], katrilyon liralik [quadrillion liras], and yatirim yaptik [we made investment]. His twitter messages thus focus on the project of "new Turkey" and economic achievements of the AKP under the leadership of Erdogan. He also announced the name of the candidates in Twitter during the municipal elections, which increases the utterance of word pairs such as "metropolitan municipality" and "mayor candidate".

The emphasis on the most used three words: "we", "Turkey", and "not" was used in the context of describing his vision of Turkey or the events. The following examples are illustrative: After the evaluation report of the European Union published in 2013, he tweeted Turkey is not a country that you can divert at the entrance door ${ }^{33}$ and after the Taksim Gezi Park movement he declared Neither the media, social media, capital nor the terrorised streets; the future of the Turkey will be determined by the nation and ballot box ${ }^{34}$; We are only accountable to the people, not to some marginal groups ${ }^{35}$. Events taking place in Taksim are not solely due to Gezi Park. These events are linked to internal and external events. ${ }^{36}$.

We should mention that his usage of the word "not" was mimicked by the opposition party members to enhance their sarcastic irony. "Not" was the most common word for Kilicdaroglu; second most common for Simsek; third most common word for Vural; fourth most common word for Kurkcu and Pave'y; eigth most common word for Demirtas; and tenth most common word for Ince. The word "not" serves Kilicdaroglu as the leader of the major opposition party to show the incongruity between what is politically unacceptable and what ought to be done instead. The following examples are drawn from the data of the first twenty popular tweets of the politicians who use the word "not". The first example is Kilicdaroglu's statement that appeared in the Twitter after the Taksim Gezi Park protests: You want everyone to vote for $A K P$, everyone to be like you, no one to make noise; but this is not Recep's Wonderland! ${ }^{37}$. With the words "not Recep's Wonderland" Kilicdaroglu stresses Erdogan's totalitarian 
tendency by adapting the title of the well-known novel of Charles Lutwidge Dodgson's Alice's Adventures in Wonderland to his name. In this way, Erdogan's political logic is unmasked via irony based on the neologism. The fifteenth most popular tweet of Kilicdaroglu gives us another example of irony based on the usage of opposite words in tweets: In Yalova, the ones that deserve won rather than the ones that were unfair. Thank you Yalova! ${ }^{38}$ Ince's tweet also uses the same style to stress the corruption claims about Erdogan and his ministers: Put your votes into the ballot box, not the shoe box ${ }^{39}$. Unlike previous examples of irony based on the creation of contrast via neologism, Kurkcu's seventh popular tweet is based on the parody of Erdogan's logic upon his comments on the protesters at the Taksim Gezi park: The prime minister is sinking as he speaks: ones that drink alcohol are alcoholics. If they have voted for $m e$, they are not alcoholics. ${ }^{40}$ Kurkcu without adding words put Erdogan's two statements in line to create a parody based on the interpretation of his logic.

\section{Conclusion}

The starting point of this study was to explore how the humorous language of the Taksim Gezi resistance affects the language of the politics and therefore to discuss what particular forms of humour were activated by politicians during the post-Gezi park period. More specifically, I discussed the relation between the conversational humour forms in the tradition of Turkish oral folk culture and the language of the Taksim Gezi Park resistance. Having defined the public square humour as the new language of oppositional politics, I examined the usage of conversational humour mechanisms by politicians. Through analysis of Twitter data, I compared politicians' adoption of the Taksim Gezi Park movement' language of humour, with its virtues of pluralism, improvisation and creativity.

The most popular tweet of our data of 23,591 samples was Erdogan's tweet "we only bow down in ruku" which illustrates the tense atmosphere in the post-Gezi Park period. As a result of the high tension, among the most popular twenty tweets of the political leaders the only tweet contains humour belongs to Demirtas, the leader of HDP. His tweet "You asked me who I was, shall we get acquainted?" appeared in order to answer Erdogan's rhetorical question Who do you think you are? asked in his public speech. The tweet was an example of his spontaneous usage of Twitter as well as an example of irony based on the misinterpretation of the context.

Upon the analysis of the first most favoured tweets of the each politician, we found the usage of following conversational humour forms: irony, exaggeration, parody, sarcasm, rhyme, word play, neologisms and proverbials. Irony is the most common mechanism used by the politicians to create humour and express political critique. The tweets indicate that the political leaders, except Demirtas, use irony to underline their political identities with references that represent either their shared experience or identities with their supporters or their differences. The finding is in parallel with studies suggesting that irony helps to heighten the criticism, elicit emotional reactions, highlight group membership and express affective attitudes (Kao and Goodman 2015). The finding is also in line with Passerat's study on the domination of irony in the political leaders' parliamentary speeches (2015). On the other hand, the analysis of the Erdogan's tweets by the frequency of the most uttered single words shows that "We", "Turkey" and "not" are the key words of the political power in the Turkish twitter sphere. The politicians of the opposition also adopt the word "not" as a means of creating ironical statements. In doing so, they are mimicking the language of the Erdogan to break the totality of his political rhetoric.

The analysis suggests that Demirtas' tweets concentrated on time-honoured mechanisms of the tradition of folk laughter revitalised by the Taksim Gezi Park spirit in two ways; 
misunderstanding of the context or the rules imposed by the political power and adaptation of the same category of thought invented by the power against to it. In this way, his humour creates moments of freedom against the repression of the political power. As the public square humour in the Taksim Gezi Park protests rejects the rules and norms of the formal political practice, Demirtas' humorous tweets also contain subversive tone of voice coming from the tradition of oral folk narratives of Nasreddin Hodja or Keloglan. In his tweets, Demirtas also uses the words or signs from the youth popular culture of social media such as the usage of neologism sapsik or Twitter symbols such as emoji. What's more, Demirtas's eight tweets were ranked among the top twenty most popular tweets of the twenty-five months long period of analysis. The findings show the link between the usage of the adoption of the public square humour forms and the popularity in Twitter sphere. Hence, the present findings confirm the earlier studies on the Taksim Gezi Park humour and its subversive potentials (Emre et al. 2014; Dagtas 2016).

As a result, the Taksim Gezi Park protests diffused a new language of talking politics that we call the public square humour, by restoring the pride of the tradition of the Turkish folk narratives and Demirtas appeared as the only one who opted to use this language. Demirtas' humorous tweets perform the three central virtues of the traditional folk humour: improvisation, creativity and pluralism. The improvisation and creativity appear in his spontaneous cleverness underlined by his quick answers, usage of the muhavere/conversation techniques by adding word play and neologisms to his utterances. His usage of humour to create more pluralistic and tolerant vision of politics was presented more specifically in his tweet 9:) furthermore I love you all 'sapsik's, including the ones that heavily criticised me. The parliamentary elections results also supported the success of the HDP to reach out to the opposition barred from politics for years. The party managed to get over the $10 \%$ national threshold to be represented by 80 deputies in the Parliament. Half of the HDP deputies were women, and almost all the ethnic and religious groups, along with trade union and gay-lesbian organisations, have their deputies under the HDP umbrella. With these features, the HDP project can be rated as outcome of the 'Gezi Park spirit' and of that political will to unite the fate of the Kurdish liberation with the libertarian aims of Turkish social movements (Vatikiotis $\&$ Yoruk 2016).

Finally, we should mention that after the 7 June 2015 election, Turkey suffered from severe terrorist attacks. A bombing attack on a massive peace rally in Ankara left more than 100 dead in October 2015, and a suicide bomber in Suruc, near Syrian border, killed 30 people in July 2015. The government ended the peace process with PKK after these attacks. On the other hand, the participatory democracy debate diffused throughout the post-Gezi park period was also suspended. Henceforth, the opposition focused to assure the right to life of the people gathering in public squares and their right to be tried fairly by the police. Considering the fact that there can be no democratic legitimacy without on-going talk, we can still emphasise the fearless festive atmosphere of the Gezi park movement which was symbolically represented its language of humour and its main instrument twitter. Humour and irony still stay in the daily life of the people as nostalgic symbols reminiscent their subversive experience. But the language of politics turned back to its previous humourless state. Thus, we can conclude that the experience of democracy lived in the public squares of the cities is something that will stay always potentially present and it can surge up anywhere and anytime (Schwarzmantel 2012). 


\section{Notes}

${ }^{1}$ According to Efe Kerem Sozeri (2015)'s study on the data-set of attack before the 7th June, 162 violent attacks realised on parties' electoral activities. The HDP was targeted of 123 of these attacks. Even before the elections the violence against the HDP was severe.

${ }^{2}$ In 1984 the Kurdistan Workers' Party, known as the PKK, began an insurrection in southeastern Anatolia. The government AKP started to open up a peace process dialogue between the captured leader of the PKK Ocalan and the representatives of the government while they pursuit the EU membership. Recently, the PKK issued a new declaration about ending the truce against the attacks of Turkish security forces. The terrorist attacks of the PKK had caused a crackdown on the legitimacy of the Kurdish parties, which resulted in their closure because of accusations of connections to the PKK.

${ }^{3}$ Twitter REST API: https://dev.twitter.com/overview/documentation

${ }^{4}$ Python programming language: https://www.python.org/

${ }^{5}$ An easy-to-use Python library for accessing the Twitter API: http://www.tweepy.org/

${ }^{6}$ ruku is part of the daily Muslim ritual, where one bends down after reciting prayers.

7 "Biz, kaderin üstündeki kadere teslim olarak mücadelemizi sürdürecek ve eğilmeyeceğiz. Biz sadece rükûda eğiliriz, başka yerde asla.” (Erdogan 25 March 2015) https://twitter.com/RT_Erdogan/status/582174363170004992 favourite count: 10,663, retweet count: 10,284.

8 "Kim olduğumu sormuşsun, tanışalım mı?@RT_Erdogan" (Demirtas 14 April 2014).https://twitter.com/hdpdemirtas/status/588036355214684160 favourite count: 4,447 , retweet count: 14,677 .

9 “Hiç mi gülmeyeceğiz? Hiç mi mutlu ve huzurlu bir gün geçirmeyeceğiz?” (Bahceli 29 October 2014). https://twitter.com/dbdevletbahceli/status/527518059863744513

10 “Gün 1şığında karanlığa mahkum edilmekten yorulduk” (Bahceli 16 March 2014). https://twitter.com/dbdevletbahceli/status/445120855618891776 favourite count: 11,066, retweet count: 11,298.

11 "Hepinize iyi geceler. Muhtesemdiniz!" https://twitter.com/FigenYuksekdag/status/607676782775529472 (Yuksekdag 7 June 2015 ) favourite count: 2,819 , retweet count: 735 .

12 "Elhamdülillah..." (Davutoglu, 6 June 2015)

https://twitter.com/Ahmet_Davutoglu/status/607202908019539968 favourite count: 25,930, retweet count: 12,835

13 “Twitter Yasağına İnat Özgürlüğe Tweet At!” (Kilicdaroglu, 21 March 2014) https://twitter.com/kilicdarogluk/status/446946019318984704 favourite count: 10,560, retweet count: 12,848

14 “Gezi Parkı'nın 2014'e girmesini yasakladığınız söyleniyor, doğru mu acaba Vali bey? @ Valimutlu" (Demirtas, 31 December 2013) https://twitter.com/hdpdemirtas/status/418067959324868609 favourite count: 326, retweet count: 260

${ }^{15} \mathrm{https}: / /$ twitter.com/oktayvural/status/414358036828811265

16 “Oyunuzu ayakkabı kutusuna değil, sandığa atın!" (Ince, 7 June 2015) https://twitter.com/vekilince/status/607447438106980352 favourite count: 2,368, retweet count: $1,797$.

17 "Yatak odasından ve ayakkabı kutusundan çıkan paraları hani polis koymuştu,Faizi ile iade edilecek paraların sahibi polis değilse, HIRSIZ vaar" (Aksener, 19 December 2014) https://twitter.com/meral_aksener/status/546027240707072000 favourite count: 1,068, retweet count: 2,793 
18 "Onlar camiye ayakkabı ile girip, içki içmiyorlardı. Bilakis camiye ayakkabı ile girip, içki içenleri denize döküyorlardı" (Erdogan, 23 June 2013)

https://twitter.com/RT_Erdogan/status/348820487641640960 favourite count: 169, retweet count: 620

19 “Acaba ayakkabılarıyla mı girdiler tünele?” (Demirtas, 25 September 2013)

https://twitter.com/hdpdemirtas/status/382774207840796672 favourite count: 289 retweet count: 429

${ }^{20} \mathrm{http}$ ://www.hurriyet.com.tr/baydemirden-tunel-tweeti-24786105 for another satirical tweet from the Mayor of Diyarbakir Baydemir elected under the HDP.

21 "Bir şehri gaz odasına çevirmek Hitler'in bile aklına gelmemişti" https://twitter.com/kilicdarogluk/status/346209116638822400 (Kilicdaroglu, 16 June 2013), favourite count: 940 , retweet count: 4500

22 "Demirtaş: "İnsanlar her yerde sokağa çıktılar. Hiçbir yerde asla şiddet kullanılmadı." Galiba uzaylılar yağmaladı, yaktı ve adam öldürdü...' (Simsek, 9 October 2014)

https://twitter.com/memetsimsek/status/520146130206998528 favourite count: 1,607 retweet count: 2,731

23 "Ustalık döneminde vatan topraklarında bayrak indirildi, konsolosluk işgal edildi,insanlarımız rehin alındı. Allah 'üstadlık' döneminden korusun" (Aksener, 13 June 2014) https://twitter.com/meral_aksener/status/477370458120421376 favourite count: 1,144, retweet count: 2,626 .

24 "Yorulduk ama değdi. Artık ampüle lüzum yok... Sabah oluyor! Bandista - Güneş Yine Doğuyor: https://t.co/t0mrnvklcL (Yuksekdag, 4 July 2015)"

https://twitter.com/FigenYuksekdag/status/585544674531794945 favourite count: 481, retweet count: 327

25 “TBMM'de hiçbir AKP'li yok... Zekeriya'dan evvel oğullarını okuldan almaya gitmişler deniyor" (Kurkcu, 12 December 2013)

https://twitter.com/ekurkcuHDP/status/412926248260612096 favourite count: 230, retweet count: 817

26 "ALLAH VAR GAM YOK"

https://twitter.com/meral_aksener/status/597944421573914626 (Aksener, 12 May 2015)

favourite count: 6,431, retweet count: 9,544

27 "CekBesmele OyunuVerEkmele"

https://twitter.com/oktayvural/status/497805856415973377 (Vural, 8 August 2014) favourite count: 379 retweet count: 1324

28 "Nehir olmayan yere köprü yaparsın; kuma tohum, kula fitne ekersin. Harama helal, yalan gerçek dersin; çünkü sen aday Erdoğan'sın.” (Bahceli, 2 August 2014) https://twitter.com/dbdevletbahceli/status/495617656054362112 favourite count: 2187 , retweet count: 3628

29 “9:) ayrıca beni çok sert eleştirenler dahil hepinizi seviyorum, şapşikler” (Demirtas, 18 December 2014) https://twitter.com/hdpdemirtas/status/545607679260250113 favourite count: 20,143, retweet count: 7,791

30 "Yine de KAZANACAĞIZ! http://t.co/mELpuCs8w4" (Demirtas, 4 June 2015) https://twitter.com/hdpdemirtas/status/606509202551513088 favourite count: 14,972, retweet count: 11,733

31 "HDP olmazsa Adam'1 sultan ederler HDP olursa Sultan'1 adam ederiz" (Demirtas 06.06.2015) https://twitter.com/hdpdemirtas/status/607249646914797569 favourite count: 12,675 retweet count: 10,109

32 "Halkların demokratik müşahitlerine kolay gelsin.Seçim yasağı nedeniyle gönlümdeki parti adını söyleyemiyorum, ama HDP olduğunu bilin istedim" 
https://twitter.com/hdpdemirtas/status/607399947059765248 (Demirtas, 7 June 2015) favourite count: 13,498, retweet count: 8,769

33 "Turkiye kapida oyalanacak bir ulke degildir" (Erdogan, 7 June 2013),

https://twitter.com/RT_Erdogan/status/342989708755861507 favourite count: 122, retweet count: 254

34 "Ne medya, ne sosyal medya, ne sermaye, ne de terörize edilen sokaklar değil;

Türkiye'nin geleceğini sadece millet ve sandık belirler" (Erdogan, 3 August 2013) https://twitter.com/RT_Erdogan/status/363692101462011904 favourite count: 412, retweet count: 1188

35 "Bize bazi marjinal gruplar degil millet hesap sorar" (Erdogan, 9 June 2013) https://twitter.com/RT_Erdogan/status/343738530431918081 favourite count:180, retweet count:678

36 "Taksim'de yaşananlar sadece Gezi Parkı olayı değildir. Bu olaylar dışarıdan ve içeriden bağlantıları olan olaylardır.” (Erdogan, 3 June 2013)

https://twitter.com/RT_Erdogan/status/341478051684708352 favourite count: 460, retweet count: 1574

37 'Herkes AKP'ye oy versin, herkes senin gibi olsun, kimse ses çıkarmasın istiyorsun; ama burası Recep Harikalar Diyarı değil!” (Kilicdaroglu, 26 June 2013).

https://twitter.com/kilicdarogluk/status/349777875282558977 favourite count: 3006, retweet count: 3817

38 "Yalova'da hak yiyen değil hak eden kazandı. Teşekkürler Yalova!" (Kilicdaroglu, 1 June 2014) https://twitter.com/kilicdarogluk/status/473188627229331456 favourtie count: 2687, retweet count: 2072

39 “Oyunuzu ayakkabı kutusuna değil, sandığa atın!” (Ince, 7 June 2015) https://twitter.com/vekilince/status/607447438106980352 favourite count: 2,368, retweet count: 1,797 .

40 "Başbakan konuştukça batıyor: "içki içen alkoliktir. Bana oy vermişse alkolik değildir" (Kurkcu, 2 June 2013) https://twitter.com/ekurkcuHDP/status/341194427999596544 favourite count: 33 , retweet count: 446.

\section{References}

Al-Momani, K., Badarneh, M. A., \& Migdadi, F. (2016). 'A semiotic analysis of political cartoons in Jordan in light of the Arab Spring'. Humor 29 (4), pp. 507-538.

Altan, C. (July 17, 2014). 'Mizah ve Siyaset'. Milliyet. Retrieved October 5, 2016 from http://www.milliyet.com.tr/mizah-ve-siyaset/gundem/ydetay/1912917/default.htm.

Anagondahalli, D. \& Khamis, S. (2014). 'Mubarak framed! Humor and political activism before and during the Egyptian Revolution'. Arab Media and Society 19, pp.1-16.

And, M. (1979). 'The Turkish Folk Theatre'. Asian Folklore Studies 38 (2), pp. 155-176.

Aral, A. (October 13, 2015). 'Bir mizah kaynagi olarak politika.' Hurriyet. Retrieved October 5, 2016 from http://www.hurriyet.com.tr/bir-mizah-kaynagi-olarak-politika-30301235.

Attardo, S. (1994). Linguistic Theories of Humor. Berlin, New York: Walter de Gruyter.

Axtmann, R. (2013). 'Conceptualising democracy'. Australian Journal of Political Science 48 (1), pp. 118-128.

Ayata, S. (2014). 'Buyurganlığa ve Yasakçılığa Karşı Direniş: 'Gezi Hareketi', Gazi Üniversiteli Öğretim Üyeleri Derneği Akademik Bülten 12 (1) Retrieved October 52016 from http://www.gaziuniversiteli.org/bulten/2014-. 1/07_S.

Bakhtin, M. M. (1984). Rabelais and His World. Bloomington: Indiana University Press. 
Baruter, B. (June 17, 2013) '30 Yil Sonra Mizah Sokaga Geri Dondu'. Hurriyet [Online]. Retrieved April 18, 2017 from http://www.hurriyet.com.tr/mizah-30-yil-sonra-sokaga-geridondu-23522576.

BBCNews. (2016). 'Turkey's Erdogan to drop lawsuits against people who insulted him'. Retrieved June 6, 2017 from http://www.bbc.com/news/world-us-canada-36925723.

Bergson, H. (1914). Laughter: An Essay on the Meaning of the Comic. Available at https://books.google.com/books?id=lrb1FMy3iMC\&printsec=frontcover\&source=gbs_ge summary $\mathrm{r} \& \mathrm{cad}=0 \# \mathrm{v}=$ onepage $\& \mathrm{q} \& \mathrm{f}=$ false.

Billig, M. (2005). Laughter and Ridicule: Towards a Social Critique of Humour. London: Sage.

Boratav, P. N. (1988). Halk Hikâyeleri ve Halk Hikâyeciligi. Adam Yayinlari, Istanbul.

Bruner, M.L. (2005). 'Carnivalesque protest and the humourless state'. Text and Performance Quarterly 25(2), pp.136-155.

Cantek, L. (2001) Markopaşa: bir mizah ve muhalefet efsanesi. Istanbul: İletişim.

Caren, N. \& Turkoglu, D. (2014). 'Political controversy has helped fuel Twitter's growth in Turkey'. The Washington Post March 28, 2014. Retrieved April 28, 2017 from https://www.washingtonpost.com/news/monkey-cage/wp/2014/03/28/politicalcontroversy-has-helped-fuel-twitters-growth-in-turkey/?utm term $=. \mathrm{b} 817 \mathrm{cdc} 5 \mathrm{fb} 8 \mathrm{c}$.

Chadwick, A. (2006). Internet Politics: States, Citizens, and New Communication Technologies. Oxford: Oxford University Press.

Cingi, A. (2011). CHP: A Party on the Road to Social Democracy. Berlin: Friedrich-EbertStiftung.

Civaoglu, G. 'Siyasette Mizah'. Milliyet May 5, 2015 [Online] Retrieved October 5, 2016 from http://www.milliyet.com.tr/siyasette-mizah/siyaset/ydetay/2054181/default.htm.

Collin, M. (2015). Pop Grenade: From Public Enemy to Pussy Riot-Dispatches from Musical Frontlines. Ropley, UK: John Hunt Publishing.

Colak, E. (2016). 'Islam Ile Gorsel Mizah:Turkiye'de Islami Mizah Dergiciliginin Donusumu'. Moment Dergi 3 (1), pp. 228-247.

Dagtas, M. S. (2016). 'Down With Some Things!' The Politics of Humour and Humour as Politics in Turkey's Cezi Protests'. Etnofoor 28 (1), pp. 11-34.

Deren, S. (2015) 'Political potential of sarcasm: cynicism in civil resentment', in Yalcintas, A. (ed). Creativity and Humour in Occupy Movements: Intellectual Disobedience in Turkey and Beyond, New York: Palgrave Macmillan, pp. 30-48.

Dogu, B., Ozcetin, B., Bayraktutan-Sutcu, G., Binark, M., Çomu, T., Aydemir, A. T., \& İslamoğlu, G. (2014). Siyasetin yeni hâli: vaka-i sosyal medya. Istanbul: Kalkedon.

Douglas, M, (2002). Purity and Danger. New York: Routledge.

Dynel, M. (2009). 'Beyond a joke: Types of conversational humour'. Language and Linguistics Compass 3 (5), pp. 1284-1299.

Egilmezler, M. 'Why do Turkish leaders fear humor?' August 21, 2016. Retrieved May 5, 2017 from http://www.yourmiddleeast.com/opinion/why-do-turkish-leaders-fear-humor_26052.

Emre, P.O., Coban, B. \& Sener, G. (2014). 'Humorous form of protest: Disproportionate use of intelligence in Gezi Park's Resistance'. Paper presented at Politsci'13 Political Science Conference, Istanbul, Turkey, 31 October-02 November. Retrieved October 5, 2016 from http://doc.utwente.nl/92922/1/Politsci13baski-libre.pdf.

Friedman, S. (2011). 'The cultural currency of a 'good' sense of humour: British comedy and new forms of distinction'. The British Journal of Sociology 62 (2), pp. 347-370.

Holquist, M. (1984). 'Prologue', in Bakhtin, M., Rabelais and his World. Bloomington: Indiana Press University Press.

Holquist. M. \& Clark, K. (1984). Mikhail Bakhtin. Cambridge: Harvard University Press.

Hurriyet. ' 22 memorable quotes by iconic Turkish politician Suleyman Demirel'. Hurriyet. Retrieved October 52016 from http://www.hurriyetdailynews.com/washington-firm-on- 
arms-saletobahrain.aspx/images/news/201201/Default.aspx?pageID=447\&GalleryID=2574\&gpid= $\underline{10}$.

Keyman, F. \& Öniş, Z. (2007). 'Globalization and social democracy in the European periphery: Paradoxes of the Turkish experience'. Globalizations 4 (2), pp. 211-228.

Göle, N. (July 29, 2013). 'Public space democracy'. Eurozine. Retrieved October 5, 2016 from http://www.eurozine.com/public-space-democracy/.

Gorkem, S. Y. (2015). 'The only thing not known how to be dealt with: Political humor as a weapon during Gezi Park Protests'. Humor 28 (4), pp. 583-609.

Graham, T., Broersma, M., Hazelhoff, K, \& van't Haar, G. (2013). 'Between broadcasting political messages and interacting with voters: The use of Twitter during the 2010 UK general election campaign'. Information, Communication \& Society 16 (5), pp. 692-716.

Gurkas, H. (2008). Nasreddin Hodja and the Akssehir Festival: Invention of a Festive Tradition and Transfigurations of a Trickster, from Bukhara to Brussels. West Lafayette, Indiana: Purdue University, Ph.D dissertation.

Kaptan, Y. (2016). 'Laugh and resist! Humor and satire use in the Gezi resistance movement'. Perspectives on Global Development and Technology 15 (5), pp. 567-587.

Kao, J.T \& Goodman, N. (2015) 'Let's talk (ironically) about the weather: Modeling verbal irony' [online]. CogSci. Retrieved April 18, 2017 from https://cocolab.stanford.edu/papers/KaoEtAl2015-Cogsci.pdf.

Kemahlığlu, Ö. (2015). 'Winds of change? The June 2015 parliamentary election in Turkey'. South European Society and Politics 20 (4), pp. 445-464.

Keyder, Ç., 2013. 'Gezi Parkı Protestoları Bağlamında Yeni Orta Sınıflar, Neoliberal Dönüşüm ve Yoksulluk'. [Online]. Retrieved October 5, 2016 from http://konusakonusa. org/2013/09/05/gezi-parkiprotestolari-baglaminda-yeni-orta-siniflar-neoliberaldonusumve-yoksulluk/.

Koc, N. (September 28, 2014). 'Erdil Yasaroglu: Muhalefet yapmak bize mi kaldi'. Diken [Online]. Retrieved April 18， 2017 from http://www.diken.com.tr/muhalefet-yapmakbize-kaldi/.

Kongar, E., \& Küçükkaya, A. (2013). Gezi direnişi. Istanbul: Cumhuriyet Kitaplari.

Kuipers, G. (2006). 'Television and taste hierarchy: the case of Dutch television comedy'. Media, Culture \& Society 28 (3), pp. 359-378.

Kuipers, G. (2008). 'The sociology of humor', in Raskin, V. (ed)., The Primer of Humor Research, Humor Research 8. pp. 365-402.

Kuipers, G. (2009) 'Humor styles and symbolic boundaries'. Journal of Literary Theory 3 (2), pp. 219-239.

Lautemann, E. (2000). 'World Encyclopedia of Political Systems and Parties by George Delury'. Reference \& User Services Quarterly 39 (3), pp. 1365-1380.

Letsch, C. (2014) 'Turkey Twitter users flout Erdogan ban on micro-blogging site'. The Guardian. $\quad$ Retrieved $\quad$ Octobe $\quad 5, \quad 2016$ from https://www.theguardian.com/world/2014/mar/21/turkey-twitter-users-flout-ban-erdogan.

Lukuslu, D. (2014) 'Cyberspace in Turkey: A 'Youthful' space for expressing powerful discontent and suffering', in Herrera, L. (ed.), Wired Citizenship: Youth Learning and Activism in the Middle East, New York: Routledge, pp. 76-88.

Makarychev, A. (2013). 'The culture of protest: Counter-hegemonic performances in Putin's Russia'. The Russian Review 72 (4), pp.653-657.

Mat, F. (2010). 'Political and religious satire in Turkey'. Retrieved June 52017 from https://www.balcanicaucaso.org/eng/Areas/Turkey/Turkish-humor-75696

Morva, O. (2016). 'The humorous language of street dissent: A discourse analysis on the graffiti of the Gezi Park protests'. The European Journal of Humour Research 4(2), pp.19-34. 
Mueller, R. (2011). 'Fun in the German parliament?', in Tsakona, V.\& Popa, D. (eds.), Studies in Political Humour: In between Political Critique and Public Entertainment. Amsterdam \& Philadelphia: John Benjamins, pp. 33-59.

Nesin, A. (2011). Sanat Yazilari. Istanbul: Nesin Yayinlari.

Sener, O. (2013). 'The Gezi protests, polyphony and 'carnivalesque chaos'. Journal of Global Faultlines 1 (2), pp. 40-42. doi:10.13169/jglobfaul.1.2.0040

Öncü, A. (2002). 'Global Consumerism, sexuality as public spectacle, and the cultural remapping of Istanbul in the 1990s', in D. Kandiyoti \& A. Sektanber (eds.), Fragments of Culture: The Everyday in Modern Turkey, New Brunswick: Rutgers University Press, pp. 171-190.

Örs, İ-R. (2014), 'Genie in the bottle: Gezi Park, Taksim Square, and the realignment of democracy and space in Turkey'. Philosophy \& Social Criticism 40 (4-5), pp. 489-498.

Ozgen, N. (2013) Bir direnis uslubu olarak mizah. BirGun Pazar (June 23),

Ozgur, I. (2012). 'Cafcaf: an Islamic humor magazine, no joke!'. Contemporary Islam 6 (1), pp.1-27.

Palmer, M. J. (2003). Taking Humour Seriously. London: Routledge.

Passerat, D . (2015). 'Siyasal Söylemde Tersinleme' [Irony in the political speech]. Humanitas - Uluslararast Sosyal Bilimler Dergisi 2 (4), pp. 207-224. DOI: 10.20304/husbd.11326

Paton, G. E., Powell, C., Venezia, L., \& Frailing, K. (1988). Humour in Society: Resistance and Control. London: Palgrave Macmillan.

Reporters Without Borders. (2016). 'Journalism ungolfed by the purge'. Retrieved June 5, 2017 from https://rsf.org/en/turkey

Reuters (2015). 'Reuters Institute Digital News Report 2015'. Retrieved April 18, 2017 from http://www.digitalnewsreport.org/essays/2015/how-turkey-uses-social-media/

Rubin, D, Nagy, P. \& Rouyer, P. (2001). The World Encyclopedia of Contemporary Theatre: Europe. Vol. 1. Oxford: Taylor \& Francis,.

Saadetyan, E. G. (2015) 'Gezi'nin Dilini Demirtaş Konuşuyor'. Birikim [Online] Retrieved October 5, 2016 from http://www.birikimdergisi.com/guncel-yazilar/1214/gezi-nin-dilinidemirtas-konusuyor\#.WALvZiMrK2w

Schwarzmantel, J. (2012) 'Insurgent Democracy'. Philosophers for change [Online]. Retrieve October 5, 2016 from https://philosophersforchange.org/2012/05/22/insurgent-democracy/

Scott, J. C. (1990). Domination and the Arts of Resistance: Hidden Transcripts. New Haven and London: Yale University Press.

Sorensen, M.J. (2014). Humorous Political Stunts: Non-violent Public Challenges to Power. Australia: University of Wollongong. Ph.D dissertation.

Stephenson, R.M. (1951). 'Conflict and control functions of humor'. American Journal of Sociology 56 (6), pp.569-574.

Sozeri, E. K. (2015). 'HDP'ye yapilan saldirilar ve cezasizlik sistemli mi?' T24 [Online] Retrieved October 5, 2016 from http://t24.com.tr/haber/hdpye-yapilan-saldirilar-vecezasizlik-sistemli-mi,296981

Tastekin, F. (2016). 'Mizahcilarin Erdogan'la imtihani cetin geciyor'. Al Monitor [Online]. Retrieved April 18, 2017 from http://www.almonitor.com/pulse/tr/originals/2016/04/turkey-political-humor-no-joke-for-satirists.html.

Tekerek, N. (2007). Soyutlama Acisindan Postmodern Edebiyat ile Meddah, Karagoz ve Ortaoyunu'nun Degerlendirilmesi. Isparta: Suleyman Demirel University, MA Thesis.

Tsakona, V., \& Popa, D. E. (eds.). (2011). Studies in Political Humour: In between Political Critique and Public Entertainment (Vol. 46). Amsterdam: John Benjamins.

Tsakona, V. (2013) 'Parliamentary punning: Is the Opposition more humorous than the ruling party?’. The European Journal of Humour Research 1 (2), pp.101-111. 
Tsakona, V. (2011) 'Irony beyond criticism: Evidence from Greek parliamentary discourse'. Pragmatics and Society 2 (1), pp. 57-86.

Tugal, C. (2013). 'Resistance everywhere': The Gezi revolt in global perspective'. New Perspectives on Turkey 49, pp.157-172.

Tugal, C. (2008). 'The greening of Istanbul'. New Left Review 51, pp. 64-80.

Tunç, A. (2001). 'Girgir as a sociological phenomenon in Turkey: The transformation of a humor magazine'. Humor 14 (3), pp. 243-254.

Turker, D. (2006). The Turkish Satiric Comedies in 1980s. Ankara: Middle East Technical University, MA Thesis.

Ümit, N. M. (2014). 'Çadirlardan saraylara, türk tiyatrosunun sahneleri' [Venues of Turkish theatre; from tents to palaces]. Art-sanat 1, pp.47-72.

Van het Hof, S. D. (2015). 'Political potential of sarcasm: Cynicism in civil resentment', in Yalcintas, A. (ed), Creativity and Humour in Occupy Movements: Intellectual Disobedience in Turkey and Beyond, New York: Palgrave Macmillan, pp. 30-47.

Vatikiotis, P. \& Yörük, Z.F. (2016). 'Gezi Movement and the networked public sphere: A comparative analysis in global context'. Social Media + Society 2 (3), pp. 1-12. https://doi.org/10.1177/2056305116662184

Wacquant, L. (2014). 'Urban inequality, marginality and social justice', Hrant Dink Memorial Lecture. $\quad$ Retrieved April 22, 2017 from https://archive.org/details/LoicWacquantInequalityMarginalityAndSocialJusticeInTheCity

Wallerstein, I., \& East, M. (2013). 'Turkey: Dilemma of the Kurds'. Reflections on TaksimGezi Park Protests in Turkey, Staffs, UK: Keele European Research Centre.

Yoruk, E., \& Yuksel, M. (2014). 'Class and politics in Turkey's Gezi protests'. New Left Review 89, pp.103-123.. 